\title{
Generation Means Analysis of three Seeds antinutrients in Cowpea (Vigna unguiculata $(\mathbf{L}$.
} Walp.)

\author{
Maina Antoine Nassourou ${ }^{1,2, *}$, Souina Dolinassou ${ }^{1}$, Mathias Julien Hand ${ }^{1}$, \\ M.M.I. Aladji Abatchoua ${ }^{2}$, Ange Ndogonoudji Alladoum ${ }^{2}$, Tchiagam Jean \\ Baptiste Noubissié ${ }^{2}$, Joseph Martin Bell ${ }^{4}$, Yanou Nicolas Njintang ${ }^{2,3}$
}

\author{
${ }^{1}$ Department of Biological Sciences, Faculty of Science, University of Maroua, P.O. Box 814, Maroua, Cameroon \\ ${ }^{2}$ Department of Biological Sciences, Faculty of Science, University of Ngaoundere, P.O. Box 454, Ngaoundere, Cameroon \\ ${ }^{3}$ Department of Food Science and Nutrition, ENSAI, University of Ngaoundere, P.O. Box 455, Ngaoundere, Cameroon \\ ${ }^{4}$ Genetics and Plant Breeding Unit, Department of Plant Biology, Faculty of Science, University of Yaounde I, P.O. Box 812, Yaounde, \\ Cameroon \\ ${ }^{*}$ Corresponding author: mainantoine@gmail.com (M.A. Nassourou)
}

\begin{abstract}
Cowpea seeds are recognized to contain some anti-nutritional factors that reduce their nutritional values. The objective of this work was to evaluate the content of tannins, flavonoids and phytic acid of cowpea seeds and to study their genetic control by using generation's means analysis $(G M A) . F_{1}$ and $F_{2}$ generations as well as backcross populations $\left(B C_{1}\right.$ and $\left.B C_{2}\right)$ were produced in three hybrid combinations by crossing six selected lines. Variation among tested varieties was from $55.12 \mathrm{mg}$ GAE/100 $\mathrm{g} d w$ (24-125B) to $233.92 \mathrm{mg} \mathrm{GAE/100} \mathrm{g} d w$ (IT97K-573-1-1) for tannins, $60.90 \mathrm{mg} / 100 \mathrm{~g} \mathrm{dw}$ (24-125B) to $557.91 \mathrm{mg} / 100 \mathrm{~g} \mathrm{dw}\left(B_{1}\right)$ for phytates and $363.64 \mathrm{mg} \mathrm{RE} / 100 \mathrm{~g} \mathrm{dw}(24-125 B)$ to $453.93 \mathrm{mg} \mathrm{RE} / 100 \mathrm{~g} \mathrm{dw}$ $\left(B R_{1}\right)$ for flavonoids. Broad-sense heritability values (0.86 to 0.99), narrow-sense heritability values (0.06 to 0.50$)$ and analysis of gene effects suggested that the antinutrients studied were controlled by additive and non-additive genes. Significant epistatic effects were found in several crosses and a duplicate type of epistasis was observed. These results suggested that breeding for increased tannins, flavonoids and phytates contents in cowpea seeds would be quite efficient through recurrent selection and selection in advanced generations.
\end{abstract}

Keywords-GMA, Cowpea, Tannins, Phytates, Flavonoids, Sudano-sahelian zone, Cameroon.

\section{INTRODUCTION}

Cowpea (Vigna unguiculata (L.) Walp.) is an annual self-pollinated plant $(2 \mathrm{n}=22$ small chromosomes $)$ (Maréchal, 1970). Africans consume the young leaves, immature pods, immature seeds, and the mature dried seeds. It is often eaten in the form of steamed cake called koki and kosai or akara donut (Kaptso et al., 2007). Seeds are also used in the formulation of simple weaning foods for children (Mensa-Wilmot et al., 2001, Egounlety 2002, Magda and Dalia 2013).

Nutritionally, cowpea seeds provide large amounts of protein, vitamins and essential minerals for human nutrition in many countries (Hall et al., 2003, Vasconcelos et al., 2010, Sreerama et al., 2012). However, its wide consumption is limited by the presence of indigestible oligosaccharides (raffinose and stachyose) that induce flatulence (Phillips et al., 2003) and some antinutritional factors such as tannins, phytates and digestive enzyme inhibitors (Towo et al., 2003, Giami 2005, Ileke 2014). These are mostly derived from the secondary metabolism of plants and limit and / or reduce the nutritional value of food (Makkar et al., 2007, Martins et al., 2011). They interfere with the bioavailability of minerals and the digestibility of essential nutrients, rendering them unavailable to cells once consumed (Jeroch et al., 1993). It is therefore necessary to eliminate or reduce these inhibitors to make the nutrients bioavailable to the body. 
Anti-nutritional substances can be eliminated or reduced by soaking, dehulling, fermentation, cooking (Egounlety and Aworth, 2003); also by soaking, grilling (Adekanmi et al., 2009); or by soaking, germinating and cooking (Ramadan, 2012). Despite their effectiveness, these methods require extra energy for households and cause a reduction of some nutrients by leaching. Some antinutrients are thermostable and their destruction by some processes is difficult. Therefore, selection of cowpea cultivars with low concentrations of these elements may be the simplest and most effective method for improving the nutritional and technological value and acceptability of cowpea (Preet and Punia, 2000; Giami, 2005). For this purpose, the evaluation of genetic variability and heritability of traits is essential for a breeding program (Noubissié et al., 2011). Thus, Adeyemi and Olorunsanya (2012), Apea-Bah et al. (2014) and Salawu et al. (2014) report some information on the genetic variability of large groups of phenolic compounds.

Genetic analyses are carried out according to several models including diallel analysis and generation's means analysis (GMA) of Mather and Jinks (1982). GMA provides information on epistasis interactions, gain from selection and heritability of traits (Allard 1960, Gamble 1962, Mather and Jinks, 1982). Compared to diallel method, it requires few controlled hybridization operations, and provides more information about genetic model (by detailing effects of various genic interactions) but requires analysis of a large number of samples for each generation. In the best of our knowledge, only Nzaramba et al. (2005) and Noubissié et al. (2012) evaluated, in cowpea, the genetic variability and heritability of phenolic compounds and antioxidant activity by 2,2-diphenyl-2picrylhydraxyl hydrate (DPPH) method. Diallel analysis and a GMA involving only four pure lines of cowpea were carried out by these researchers. In the Sudano-Sahelian zone of Cameroon, there is a dearth of information regarding the genetic analyses of biochemical characters of cowpea genotypes. Thus, this study was designed to evaluate tannins, flavonoids and phytates contents of cowpea genotypes, and to determine their genetic model heritability in the Sudano-Sahelian zone of Cameroon.

\section{MATERIAL AND METHODS}

\section{Plant materials and field experiments}

Field experiments were conducted from 2011 to 2014 at the Institute of Agricultural Research for Development (IRAD) farm of Giring-Maroua $\left(09^{\circ} 30^{\prime} \mathrm{N}\right.$, $10^{\circ} 32^{\prime}$ E) located in the Sudano-Sahelian zone of Cameroon.
The study was carried out on 15 cowpea genotypes (Nassourou et al., 2015) including two local landraces and 13 improved lines developed by IRAD and the International Institute of Tropical Agriculture (IITA). Generation means analysis (GMA) was based on six populations ( $\mathrm{P}_{1}$ and $\mathrm{P}_{2}$ parents, $\mathrm{F}_{1}$ hybrids, $\mathrm{F}_{2}$ generations, and $\mathrm{BC}_{1}$ and $\mathrm{BC}_{2}$ backcrosses) obtained from three combinations: IT97K-573-1-1 x 24-125B, B301 x BR 1 and CRSP x Lori.

Preliminary trials were conducted during the rainy season in 2011 and 2012 to ensure purity of genotypes and to assess their variability for tannins, phytates and flavonoids. Experimentations were conducted in a randomized complete block design (RCBD) with three replications. Seeds of selected parents were sown during the 2013 rainy season for crossings (Nassourou et al., 2015). Parents of respective crosses were used as male parent and $\mathrm{F}_{1}$ hybrids as female parent to produce $\mathrm{BC}_{1}$ and $\mathrm{BC}_{2}$ ( $\mathrm{F}_{1}$ backcrossed to $\mathrm{P}_{1}$ and $\mathrm{P}_{2}$ respectively) seeds, and $\mathrm{F}_{1}$ hybrids were selfed to obtain $\mathrm{F}_{2}$ seeds. All 15 pure lines and hybrids obtained were planted in a RCBD with three replications during the 2014 rainy season. The number of plants sampled is 10 for $\mathrm{P}_{1}, \mathrm{P}_{2}$ and $\mathrm{F}_{1} ; 25$ for $\mathrm{F}_{2}$; and 15 in $\mathrm{BC}_{1}$ and $\mathrm{BC}_{2}$.

\section{Biochemical analysis}

Extraction of tannins was done by adding $100 \mathrm{mg}$ of polyvinyl polypyrrolidone (PVPP) to $1.0 \mathrm{~mL}$ of distilled water and $1.0 \mathrm{~mL}$ of the methanolic extract of total polyphenols (Makkar et al., 1993; Nassourou et al., 2015). Tannins get bound to PVPP, and then the clear supernatant contained only non-tannin phenolics.

Non-tannin phenolics were determined using the Folin-Ciocalteu method (Gao et al., 2000). Absorbance was read at $725 \mathrm{~nm}$ against a blank reagent. Results were expressed as $\mathrm{mg}$ gallic acid equivalent (GAE) per $100 \mathrm{~g}$ dry weight $(\mathrm{dw})$. Tannins content of the sample was evaluated by difference between non-tannin phenolics and total polyphenols contents (Nassourou et al., 2015).

Total flavonoid content was determined following Noudeh et al. (2010) based on the flavonoid-aluminum complex with maximum absorption at $430 \mathrm{~nm}$. A calibration curve was prepared with a $1 \mathrm{mg} \mathrm{mL}^{-1}$ solution of rutin (Miyase et al., 1992), and results were expressed as $\mathrm{mg}$ rutin equivalent (RE) on a dry matter basis.

Phytic acid was determined according to Wade reagent's method $\left(30 \mathrm{mg}\right.$ of $\mathrm{FeCl}_{3} \cdot 6 \mathrm{H}_{2} \mathrm{O}$ and $300 \mathrm{mg}$ of sulfosalicylic acid dissolve in approximately $70 \mathrm{~mL}$ distilled water, and volume completed to $100 \mathrm{~mL}$ with distilled water) described by Vaintraub and Lapteva (1988). The absorbance was read at $500 \mathrm{~nm}$ against a 
blank reagent. Phytate concentration was calculated from the difference between control absorbance $(3 \mathrm{~mL}$ of water $+1 \mathrm{~mL}$ Wade reagent) and sample absorbance. Calibration curve was drawn using a solution of sodium phytate diluted to obtain 5 to $40 \mu \mathrm{g}$ of phytic acid. Results were expressed in mg per $100 \mathrm{~g}$ dry matter basis.

\section{Statistical analysis}

Studied antinutrients data were subjected to analysis of variance (ANOVA) using STATGRAPHICS Plus 5.0 (Manugistics, 1997).

Three scaling tests $\mathrm{A}, \mathrm{B}$ and $\mathrm{C}$ were performed to test the adequacy of the additive-dominance model (Mather and Jinks, 1982) as follows:

$$
\begin{aligned}
& A=2 \overline{B C_{1}}-\overline{P_{1}}-\overline{F_{1}} \\
& V A=4 V\left(\overline{B C_{1}}\right)+V\left(\overline{P_{1}}\right)+V\left(\overline{F_{1}}\right) \\
& B=2 \overline{B C_{2}}-\overline{P_{2}}-\overline{F_{1}} \\
& V B=4 V\left(\overline{B C_{2}}\right)+V\left(\overline{P_{2}}\right)+V\left(\overline{F_{1}}\right) \\
& C=4 \overline{F_{2}}-2 \overline{F_{1}}-\overline{P_{1}}-\overline{P_{2}} \\
& V C=16 V\left(\overline{F_{2}}\right)+4 V\left(\overline{F_{1}}\right)+V\left(\overline{P_{1}}\right)+V\left(\overline{P_{2}}\right) \\
& S E(A)=(V A)^{\frac{1}{2}} \quad t(A)=A / S E(A) \\
& S E(B)=(V B)^{\frac{1}{2}} \quad t(B)=B / S E(B) \\
& S E(C)=(V C)^{\frac{1}{2}} \quad t(C)=C / S E(C)
\end{aligned}
$$

Where, $A, B$ and $C$ are scaling test parameters,

$\mathrm{SE}=$ standard error,

$V=$ variance, $\overline{P_{1}}, \overline{P_{2}}, \overline{F_{1}}, \overline{F_{2}}, \overline{B C_{1}}$ and $\overline{B C_{1}}$ are means of parent 1 , parent $2, \mathrm{~F}_{1}$ hybrids, $\mathrm{F}_{2}$ progenies, and backcrosses generations $\mathrm{BC}_{1}$ and $\mathrm{BC}_{2}$, respectively.

In case of proven inadequacy of additivedominance model, the model of six-parameter generation analysis proposed by Gamble (1962) was used. Various genetic parameters i.e., mid-parent values $[m]$, additive gene effects $[d]$, dominance deviation $[h]$ and the three non-allelic interactions (additive $\mathrm{x}$ additive $[i]$, additive $\mathrm{x}$ dominance $[j]$ and dominance $\mathrm{x}$ dominance $[l]$ ) were defined as follows:

$$
\begin{aligned}
& m=\overline{F_{2}} \\
& d=\overline{B_{1}}-\overline{B_{2}} \\
& h=-1 / 2 \overline{P_{1}}-1 / 2 \overline{P_{2}}+\overline{F_{1}}-4 \overline{F_{2}}+2 \overline{B_{1}}+2 \overline{B_{2}} \\
& i=-4 \overline{F_{2}}+2 \overline{B_{1}}+2 \overline{B_{2}} \\
& j=-1 / 2 \overline{P_{1}}+1 / 2 \overline{P_{2}}+\overline{B_{1}}-\overline{B_{2}} \\
& l=\overline{P_{1}}+\overline{P_{2}}+2 \overline{F_{1}}+4 \overline{F_{2}}-4 \overline{B_{1}}-4 \overline{B_{2}}
\end{aligned}
$$

Student's t-test was used to test scaling test parameters and genetic parameters at 5\%,1\% and $0.1 \%$ level of significance. In each test, degrees of freedom are the sum of degrees of freedom of various generations involved (Mather, 1949).

Broad-sense heritability $\left(\mathrm{h}^{2}\right)$ and narrow-sense heritability $\left(\mathrm{h}_{\mathrm{n}}^{2}\right)$ were calculated using the backcross method (Warner, 1952; Mather and Jinks, 1982):

$$
h^{2}=s_{g}^{2} / s^{2}{ }_{p} \text { and } h_{n}{ }^{2}=s_{A}^{2} / s^{2}{ }_{p}
$$

Where, additive variance $\left(s_{A}^{2}\right)=2 s_{F 2}^{2}-\left(s_{B C 1}^{2}+\right.$ $\left.S^{2}{ }_{B C 2}\right)$; phenotypic variances $\left(\sigma_{p}^{2}\right)=\left(s_{F 2}^{2}\right)$; environmental variances in $\mathrm{F}_{2}\left(s_{E}^{2}\right)=1 / 4\left(2 s_{F 1}^{2}+\right.$ $\left.s_{P 1}^{2}+s_{P 2}^{2}\right)$ and genetic variance $\left(s^{2}{ }_{g}\right)=s^{2}{ }_{p}-s_{E}^{2}$ (Wright, 1968).

\section{RESULTS}

\section{Generation's means}

Significant difference was noted between the six evaluated generations for tannin, phytate and flavonoid contents (Table 1). Significant transgressive forms were observed and $F_{2}$ population had higher values than better parents. This was the case of tannins for $\mathrm{BR}_{1} \times \mathrm{B} 301$, phytates and flavonoids for IT97K-573-1-1 x 24-125B and flavonoids for CRSP x Lori. 
International Journal of Environment, Agriculture and Biotechnology, 5(5)

Sep-Oct, 2020 / Available: https://ijeab.com/

Table 1. Mean and standard error of six generations with three crosses for tannins, phytates and flavonoids in cowpea seeds

\begin{tabular}{|c|c|c|c|}
\hline Traits and generations & $\mathrm{BR}_{1} \times \mathrm{B301}$ & IT97K-573-1-1 x 24-125B & CRSP x Lori \\
\hline \multicolumn{4}{|l|}{ Tannins } \\
\hline $\mathrm{P}_{1}$ & $84.19 \pm 3.76^{\mathrm{d}}$ & $233.92 \pm 9.22^{f}$ & $216.00 \pm 9.17^{\mathrm{e}}$ \\
\hline $\mathrm{P}_{2}$ & $73.57 \pm 5.00^{c}$ & $55.12 \pm 6.45^{\mathrm{a}}$ & $105.04 \pm 8.17^{\mathrm{a}}$ \\
\hline $\mathrm{F}_{1}$ & $94.12 \pm 0.76^{\mathrm{e}}$ & $85.56 \pm 9.59^{c}$ & $144.07 \pm 9.29^{c}$ \\
\hline $\mathrm{F}_{2}$ & $85.45 \pm 32.85^{\mathrm{d}}$ & $149.84 \pm 69.72^{\mathrm{e}}$ & $200.56 \pm 27.79^{d}$ \\
\hline $\mathrm{BC}_{1}$ & $70.12 \pm 33.44^{b}$ & $140.92 \pm 87.43^{\mathrm{d}}$ & $144.70 \pm 23.08^{b}$ \\
\hline $\mathrm{BC}_{2}$ & $61.19 \pm 28.20^{\mathrm{a}}$ & $65.36 \pm 31.12^{b}$ & $104.41 \pm 25.31^{\mathrm{a}}$ \\
\hline \multicolumn{4}{|l|}{ Phytates } \\
\hline $\mathrm{P}_{1}$ & $557.91 \pm 1.46^{\mathrm{c}}$ & $94.94 \pm 6.16^{\mathrm{b}}$ & $419.31 \pm 26.14^{\mathrm{f}}$ \\
\hline $\mathrm{P}_{2}$ & $266.38 \pm 9.10^{\mathrm{a}}$ & $60.90 \pm 4.87^{\mathrm{a}}$ & $138.03 \pm 9.00^{\mathrm{a}}$ \\
\hline $\mathrm{F}_{1}$ & $1044.67 \pm 28.36^{f}$ & $160.15 \pm 11.49^{\mathrm{e}}$ & $383.13 \pm 16.06^{\mathrm{d}}$ \\
\hline $\mathrm{F}_{2}$ & $491.53 \pm 114.17^{b}$ & $145.23 \pm 50.32^{\mathrm{d}}$ & $331.72 \pm 82.72^{\mathrm{c}}$ \\
\hline $\mathrm{BC}_{1}$ & $888.03 \pm 115.66^{\mathrm{e}}$ & $186.14 \pm 47.19^{f}$ & $387.51 \pm 77.12^{\mathrm{e}}$ \\
\hline $\mathrm{BC}_{2}$ & $628.99 \pm 108.91^{\mathrm{d}}$ & $125.33 \pm 44.36^{\mathrm{c}}$ & $296.05 \pm 74.79^{b}$ \\
\hline \multicolumn{4}{|l|}{ Flavonoids } \\
\hline $\mathrm{P}_{1}$ & $453.93 \pm 20.01^{\mathrm{e}}$ & $436.42 \pm 17.39^{\mathrm{c}}$ & $409.73 \pm 11.73^{\mathrm{d}}$ \\
\hline $\mathrm{P}_{2}$ & $400.78 \pm 22.71^{b}$ & $363.64 \pm 14.37^{\mathrm{a}}$ & $386.87 \pm 8.86^{c}$ \\
\hline $\mathrm{F}_{1}$ & $380.63 \pm 5.52^{\mathrm{a}}$ & $462.70 \pm 11.65^{\mathrm{e}}$ & $381.03 \pm 4.19^{b}$ \\
\hline $\mathrm{F}_{2}$ & $406.41 \pm 52.68^{c}$ & $445.04 \pm 37.59^{\mathrm{d}}$ & $433.98 \pm 27.96^{\mathrm{f}}$ \\
\hline $\mathrm{BC}_{1}$ & $430.54 \pm 44.23^{\mathrm{d}}$ & $406.28 \pm 39.29^{b}$ & $425.87 \pm 26.21^{\mathrm{e}}$ \\
\hline $\mathrm{BC}_{2}$ & $494.42 \pm 51.49^{\mathrm{f}}$ & $476.51 \pm 31.36^{\mathrm{f}}$ & $362.16 \pm 22.01^{\mathrm{a}}$ \\
\hline
\end{tabular}

Tannins (mg GAE/100 g dw); Phytates (mg/100 g dw); Flavonoids (mg RE/100 g dw);means followed by same letters in a cross for a trait, are not significantly different at $5 \%$ probability level

\section{Variance components and heritability}

Different components of phenotypic variance for tannin, phytate and flavonoid contents are shown in Table 2. Genetic variance was higher than environmental variance for all traits and variance due to dominance effects was the largest component of genetic variance. CRSP $x$ Lori cross revealed a slight superiority of additive variance for tannins and flavonoids. Broad and narrow sense heritability ranged from 0.86 to 0.99 and from 0.06 to 0.50 respectively (Table 3 ) depending on the parameters studied (tannins, phytates or flavonoids) and combination. The large difference observed between broad sense heritability and narrow sense heritability was an indicator of dominance effects of genes. 
Table 2. Means \pm standard error, scaling test and genetic effects for tannins, phytates and flavonoids in cowpea seeds

\begin{tabular}{|c|c|c|c|c|c|c|c|c|c|c|}
\hline Cross & $\mathbf{A}$ & B & $\mathbf{C}$ & Mean $[m]$ & Additive $[d]$ & Dominance $[h]$ & $\begin{array}{c}\text { Additive x Additive } \\
{[i]}\end{array}$ & $\begin{array}{c}\text { Additive x Dominance } \\
{[j]}\end{array}$ & $\begin{array}{c}\text { Dominance x Dominance } \\
{[l]}\end{array}$ & $\begin{array}{l}\text { Type of } \\
\text { epistasis }\end{array}$ \\
\hline \multicolumn{11}{|c|}{ Tannins } \\
\hline $\mathrm{C}_{1}$ & * & $*$ & ns & $85.45 \pm 32.85^{* *}$ & $8.93 \pm 43.74$ & $-63.93 \pm 157.89^{*}$ & $-79.17 \pm 157.86^{*}$ & $3.62 \pm 43.85$ & $162.56 \pm 218.91^{* * *}$ & $\mathrm{D}$ \\
\hline $\mathrm{C}_{2}$ & ns & $\mathrm{ns}$ & $\mathrm{ns}$ & $149.84 \pm 69.72^{* * *}$ & $75.56 \pm 92.80^{*}$ & $-245.77 \pm 335.18^{* * *}$ & I & I & I & $\mathrm{D}$ \\
\hline $\mathrm{C}_{3}$ & ns & $\mathrm{ns}$ & $* *$ & $200.56 \pm 27.79^{* * *}$ & $40.29 \pm 34.25^{*}$ & $-320.55 \pm 131.05^{* * *}$ & $-304.02 \pm 130.57^{* * *}$ & $-15.27 \pm 34.80$ & $415.14 \pm 177.83^{* * *}$ & $\mathrm{D}$ \\
\hline \multicolumn{11}{|c|}{ Phytates } \\
\hline $\mathrm{C}_{1}$ & ns & $\mathrm{ns}$ & $* * *$ & $491.53 \pm 114.17^{* *}$ & $258.36 \pm 158.87^{* *}$ & $1699.12 \pm 557.08^{* * *}$ & $1066.60 \pm 506.50^{* * *}$ & $112.60 \pm 158.93^{*}$ & $-1185.68 \pm 784.65^{* * *}$ & $\mathrm{D}$ \\
\hline $\mathrm{C}_{2}$ & $* *$ & $\mathrm{~ns}$ & ns & $145.23 \pm 50.32^{* * *}$ & $60.31 \pm 64.77^{*}$ & $125.25 \pm 239.67^{*}$ & $43.02 \pm 239.35$ & $43.29 \pm 64.89^{*}$ & $-190.82 \pm 328.97^{* *}$ & $\mathrm{D}$ \\
\hline $\mathrm{C}_{3}$ & $\mathrm{~ns}$ & $\mathrm{~ns}$ & $\mathrm{~ns}$ & $331.72 \pm 82.72^{*}$ & $91.46 \pm 107.43$ & $108.46 \pm 395.09$ & I & I & I & $\mathrm{D}$ \\
\hline \multicolumn{11}{|c|}{ Flavonoids } \\
\hline $\mathrm{C}_{1}$ & $\mathrm{~ns}$ & $\mathrm{~ns}$ & $*$ & $406.41 \pm 52.68^{* * *}$ & $-63.88 \pm 67.88^{*}$ & $177.54 \pm 251.18^{* *}$ & $224.27 \pm 250.67^{* *}$ & $-37.30 \pm 69.55$ & $-458.21 \pm 345.20^{* * *}$ & $\mathrm{D}$ \\
\hline $\mathrm{C}_{2}$ & $*$ & $*$ & $\mathrm{~ns}$ & $445.04 \pm 37.59^{* * *}$ & $-70.23 \pm 50.27^{* *}$ & $48.12 \pm 181.60$ & $-14.56 \pm 180.88$ & $-106.63 \pm 51.52^{* * *}$ & $-25.56 \pm 253.17$ & $\mathrm{D}$ \\
\hline $\mathrm{C}_{3}$ & $*$ & $\mathrm{~ns}$ & $* *$ & $433.98 \pm 27.96^{* * *}$ & $63.72 \pm 34.23^{*}$ & $-177.12 \pm 131.40^{* * *}$ & $-159.85 \pm 131.13^{*}$ & $75.15 \pm 35.01^{* * *}$ & $142.44 \pm 177.59^{* *}$ & $\mathrm{D}$ \\
\hline
\end{tabular}

C1 = BR 1 x B301; C2 = IT97K-573-1-1 x 24-125B; C3 = CRSP x Lori; Tannins (mg GAE/100 g dw); Phytates (mg/100 g dw); Flavonoids (mg RE/100 g dw); $m=$ mid-parent values; $[d]=$ additive; $[h]=$ dominance; $[i]=$ additive $\mathrm{x}$ additive; $[j]=$ additive $\mathrm{x}$ dominance; $[l]=$ dominance $\mathrm{x}$ dominance.

${ }^{*},{ }^{* *},{ }^{* * *}$ : Significance at $\mathrm{P} \leq 0.05,0.01$ or 0.001 respectively

Table 3. Estimates of heritability for tannins, phytates and flavonoids in cowpea seeds

\begin{tabular}{|c|c|c|c|c|c|c|}
\hline \multirow[t]{2}{*}{ Trait } & \multicolumn{2}{|c|}{ BR1 x B301 } & \multicolumn{2}{|c|}{ IT97K-573-1-1 x 24-125B } & \multicolumn{2}{|c|}{ CRSP x Lori } \\
\hline & $h^{2}$ & $h_{n}^{2}$ & $h^{2}$ & $h_{n}^{2}$ & $h^{2}$ & $h_{n}^{2}$ \\
\hline Tannins & 0.99 & 0.23 & 0.98 & 0.23 & 0.90 & 0.48 \\
\hline Phytates & 0.97 & 0.06 & 0.97 & 0.34 & 0.95 & 0.31 \\
\hline Flavonoids & 0.91 & 0.34 & 0.86 & 0.21 & 0.92 & 0.50 \\
\hline
\end{tabular}

$h^{2}$ : Broad-sense heritability; $h_{\mathrm{n}}^{2}$ : Narrow-sense heritability. 


\section{Scaling joint tests and gene effects}

Means values for the scaling joint tests are presented in Table 2. These tests were carried out for tannins, phytates and flavonoids and indicated the presence of non-allelic interactions in some cases. A and B scaling tests provided evidence for the presence of additive $\mathrm{x}$ additive $(i)$, additive $\mathrm{x}$ dominance $(j)$ and dominance $\mathrm{x}$ dominance $(l)$ type gene interactions. Thus, we observed significant $\mathrm{A}$ and $\mathrm{B}$ tests for tannins in cross $\mathrm{C} 1$ and flavonoids in cross $\mathrm{C} 2$; exhibiting presence of non-allelic or epistatic interactions for studied traits. The $\mathrm{C}$ scaling test provided a test for type $l$ epistasis. Significant $\mathrm{C}$ test was observed in almost all traits according to crosses involved.

Additive $(d)$ and dominance $(h)$ effects are significant, and dominance seems to be more important for these traits, except for tannins (all combinations) and flavonoids (CRSP x Lori). Additive and dominance effects as well as additive-additive $(i)$, additive-dominance $(j)$ and dominance-dominance $(l)$ interactions were also significant for all traits and combinations. Gene effects are all positive for phytates apart from dominance-dominance (l) interaction that showed negative values. On the other hand, for all parameters, significant $h$ and $l$ effects were noted and had different signs indicating a double epistasis type for these characters.

\section{DISCUSSION}

Gene actions of some secondary metabolites (tannins, phytates and flavonoids) have been clarified through generation means analysis. Specifically, flavonoids content is known to be dominantly influenced by both genotype and environment (Dwivedi et al., 2016). High values of broad sense heritability were noted in all combinations (BR 1 x B301, IT97K-573-1-1 x 24-125B and CRSP x Lori) for antinutrients. Thus, their levels can be improved genetically under the experimental conditions of Sudano-Sahelian zone. Narrow sense heritability showed values of $50 \%$ or less suggesting that these characters are predominantly under the control of non-additive genes effects. In previous work, Noubissié et al. (2012) concluded that phenols (tannin-related group) are highly heritable and predominantly controlled by additive genes. Overall, values of broad sense heritability were very high and showed that tannins, phytates and flavonoids are inherited from parents to offspring. In addition, genes involved were mainly non-additive effects and the choice of complementary parents is therefore more appropriate to improve these characters. In previous work, Nassourou et al. (2016) have noted that both additive and non-additive gene effects controlled flavonoids and antioxidant properties with a preponderance of non-additive gene effects.

Apart from additive and dominance, which were the main factors controlling the studied antinutrients, epistatic interactions were also significant. Significant epistasis has been previously reported for total phenols content in cowpea using a generation's means analysis (Noubissié et al., 2012); also by using a diallel analysis (Nassourou et al., 2015; 2016). Indeed, epistasis is usually due to a high level of homozygosity in self-pollinated species (Volis et al., 2010). According to Kearsey and Pooni (1996), the type of epistasis is determined only when dominance $(h)$ and dominance $\mathrm{x}$ dominance $(l)$ effects are significant, when these effects have the same sign; effects are complementary while different signs indicated duplicate epistasis. For all these, dominance and dominance $\mathrm{x}$ dominance $(l)$ interactions are always of opposite sign; which refers to a case of duplicate epistasis. The same conclusion was reported for phenol content of Solanum melongena by Sabolu et al. (2014). This type of epistasis generally hinders improvement by selection and therefore, significant effects of dominance and dominance $\mathrm{x}$ dominance interaction would not be desirable. Overall, for tannins and flavonoids, additive-additive $(i)$ interaction is negative, showing a dispersion of parental alleles for these traits.

Genetic improvement of nutritional value of cowpea seeds by reducing antinutrient levels is possible by exploiting the wide genetic variability and using appropriate breeding techniques. Due to significant epistasis observed, selection for these traits would be most effective at latter generations by using pedigree method and recurrent selection (Allard, 1960; Santos et al., 2012). For the pedigree method, selection would be postponed in $\mathrm{F}_{6}$ generations and operated in bulk or by single-seed or single-pod descent (Demarly, 1977, Bernado, 2003). These methods being particularly expensive, time consuming and laborious, marker assisted selection would also be recommended for more efficiency.

\section{ACKNOWLEDGMENTS}

This work was supported in part by funds from International Foundation for Science (C/5262-1). The authors are grateful to Institute of Agricultural Research for Development (IRAD) of Maroua-Cameroon for kindly providing seed samples and field experiments. 


\section{REFERENCES}

[1] Adekanmi O.K., Oluwatooyin O.F. \& Yemisi A.A., 2009. Influence of processing techniques on the nutrients and antinutrients of tigernut (Cyperus esculentus L.). World J. Dairy Food Sci., 4(2): 88-93.

[2] Adeyemi K.D. \& Olorunsanya A.O., 2012. Comparative analysis of phenolic composition and antioxidant effect of seed coat extracts of four cowpea (Vigna unguiculata) varieties on broiler meat. Iranian J. Appl. Anim. Sci., 4(2): 343-349.

[3] Allard R.W., 1960. Principles of plant breeding. John Wiley and Sons, Inc., New-York. USA, 512 p.

[4] Apea-Bah F., Minnaar A., Bester M.J. \& Duodu K.G., 2014. Does a sorghum-cowpea composite porridge hold promise for contributing to alleviating oxidative stress? Food Chem., 157: 157-166.

[5] Bernado R., 2003. On the effectiveness of early selection in self-pollinated crops. Crop Sci., 43: 1558-1560.

[6] Demarly Y., 1977. Génétique et amélioration des plantes.Ed. Masson, Paris VI, 287 p.

[7] Dwivedi S.L., Upadhyaya H.D., Chung I.-M., De Vita P., García-Lara S., Guajardo-Flores D., GutiérrezUribe J.A., Serna-Saldívar S.O., Rajakumar G., Sahrawat K.L., Kumar J.\& Ortiz R., 2016. Exploiting phenylpropanoid derivatives to enhance the nutraceutical values of cereals and legumes. Front. Plant Sci., 7:763.

[8] Egounlety M. \& Aworh O.C., 2003. Effect of soaking, dehulling, cooking and fermentation with Rhizopus oligosporus on the oligosaccharides, trypsin inhibitor, phytic acid and tannins of soybean (Glycine max Merr.), cowpea (Vigna unguiculata L. Walp.) and groundbean (Macrotyloma geocarpa Harms). J. Food Eng., 56: 249254.

[9] Egounlety M., 2002. Production of legume-fortified weaning foods. Food Res. Int.,35: 233-237.

[10] Gamble E.E., 1962. Gene effects in corn (Zea mays L.): separation and relative importance of gene effects for yield. Can. J. Plant Sci.,42: 339-348.

[11] Gao X., Ohlander M., Jeppsson N., Björk L. \& Trajkovski V., 2000. Changes in antioxidant effects and their relationship to phytonutrients in fruits of sea buckthorn (Hippophae rhamnoides L.) during maturation. J. Agric. Food Chem., 48: 1485-1490.

[12] Giami S.Y., 2005. Compositional and nutritional properties of selected newly developed lines of cowpea (Vigna unguiculata L. Walp.). J. Food Compos. Anal., 18: 665673.

[13] Hall E.A., Cissé N., Thiaw S., Elawad H.O.A., Ehlers J.D., Ismail A.M., Fery R.L., Roberts P.A., Kitch L.W., Murdock L.L., Boukar O., Phillips R.D. \& Mc Watters K.H., 2003. Development of cowpea cultivars and germplasm by the Bean/Cowpea CRSP. Field Crops Res., 82: 103-134.

[14] Ileke K.D., 2014. Anti-nutritional factors in cowpea cultivars and their effects on susceptibility to Callosobruchus maculatus (Fab.) [Coleoptera: Bruchidae] infestation. Biosci. Methods, 5(2): 1-8.
[15] Jeroch H., Flachowsky G. \& Weißbach F., 1993. Futtermittelkunde (Handbook of Feed Ingredients), GustavFisher-Verlag Jena, Stuttgart, $510 \mathrm{p}$.

[16] Kaptso K.G., Njintang N.Y., Hounhouigan J.D., Scher J., Mbofung C.M.F., 2007. Production of Bambara groundnut (Voandzeia subterranea) flour for use in the preparation of koki (a steamed cooked paste): effect of $\mathrm{pH}$ and salt concentration on the physicochemical properties of flour, Int. J. Food Eng.,3(3): 1-20.

[17] Kearsey M.J.\& Pooni H.S., 1996. The genetic analysis of quantitative traits. $1^{\text {st }}$ edition. Chapman and Hall, London.

[18] Magda S.M. \& Dalia M.E-N., 2013. Nutritional evaluation of weaning food blends fortified with some carotenoids-rich vegetables. J. Appl. Sci. Res., 9(3): 15731582.

[19] Makkar H.P.S., Blummel M., Borowy N.K. \& Becker, 1993. Gravimetric determination of tannins and their correlations with chemical and protein precipitation methods. J. Sci. Food Agric., 61: 161-165.

[20] Makkar H.P.S., Siddhuraju P. \& Becker K., 2007. Plant Secondary Metabolites. In: Walker J.M. (eds.), Methods in Molecular Biology, Humana Press Inc., Totowa, New Jersey, vol. 393, 130 p.

[21] Manugistics, 1997. Statgraphics Plus 5.0 for Windows. Manugistics Inc., Rockville, Maryland.

[22] Martins S., Mussatto S.I., Martínez-Avila G., Montañez-Saenz J., Aguilar C.N. \& Teixeira J.A., 2011. Bioactive phenolic compounds: production and extraction by solid-state fermentation. A review. Biotechnol. Adv., 29: 365-373.

[23] Mather K.\& Jinks J.L., 1982. Biometrical Genetics: The study of continuous variation, $3^{\text {rd }}$ ed. Chapman and Hall, London, New York.

[24] Mather K., 1949. Biometrical Genetics. Dover publication, Inc. New York.

[25] Mensa-Wilmot Y., Phillips R.D. \& Hargrove J.L., 2001. Protein quality evaluation of cowpea-based extrusion cooked cereal/legume weaning mixtures. Nutr. Res., 21: 849-857.

[26] Miyase T., Kohsaka H. $\quad$ \& $\quad$ Ueno A., 1992. Tragopogonosids A-I, oleanane saponins from Tragopogon pratensis. Phytochemistry31: 2087-2091.

[27] Nassourou M.A., Noubissié T.J-B., Gonne S., Hamadama Y., Bell J.M. \& Njintang Y.N., 2015. Diallel analysis of polyphenols and phytates content in cowpea (Vigna unguiculata L. Walp.). Scientia Agriculturae, 12(1): 46-51.

[28] Noubissié T.J-B., Bell J.M., Nassourou M.A., Njintang Y.N. \& Youmbi E., 2011. Genetic analysis of seed proteins contents in cowpea (Vigna unguiculata (L.) Walp.). Afr. J.Biotechnol., 10(16): 3077-3086.

[29] Noubissié T.J-B., Youmbi E., Njintang Y.N., Aladji Abatchoua M., Nguimbou R.M. \& Bell J.M., 2012. Inheritance of phenolic contents and antioxidant capacity of dehulled seeds in cowpea (Vigna unguiculata L. Walp.). Int. J. Agr. Agri. Res., 2(3): 7-18. 
[30] Noudeh G.D., Sharififar F., Khatib M., Behravan E. \& Afzadi M.A., 2010. Study of aqueous extract of three medicinal plants on cell membrane-permeabilizing and their surface properties. Afr. J.Biotechn., 9: 110-116.

[31] Nzaramba M.N., Hale A.L., Schewing D.C. \& Miller J.C., 2005. Inheritance of antioxidant activity and its association with seed coat colour in cowpea. J. Am. Soc. Hort. Sci., 130(3): 386-391.

[32] Phillips R.D., McWatters K.H., Chinnan M.S., Hung Y.C., Beuchat L.R., Sefa-Dedeh S., Sakyi-Dawson L., Ngoddy P., Nnanyelugo D., Enwere J., Komey N.S., Liu K., Mensa-Wilmot Y., Nnanna I.A., Okeke C., Prinyawiwatkul W. \& Saalia F.K., 2003. Utilization of cowpeas for human food. Field Crops Res., 82: 193-213.

[33] Preet K. \& Punia D., 2000. Proximate composition, phytic acid, polyphenols and digestibility (in vitro) of four brown cowpea varieties. Int. J. Food Sci. Nutr., 51: 189-193.

[34] Ramadan E.A., 2012. Effect of processing and cooking methods on the chemical composition, sugars and phytic acid of soybeans. Food and Public Health, 2(1): 11-15.

[35] Sabolu S., Kathiria K.B., Mistry C.R. \& Kumar S., 2014. Generation mean analysis of fruit quality traits in eggplant (Solanum melongena L.). AJCS, 8(2): 243-250.

[36] Salawu O.S., Oluwafemi I.E., Oladipupo D. \& Bukola B.O.S., 2014. Effect of Callosobruchus maculatus infestation on the nutrient-antinutrient composition, phenolic composition and antioxidant activities of some varieties of cowpeas (Vigna unguiculata). Adv. J. Food Sci. Technol., 6(3): 322-332.

[37] Santos C.A.F., da Costa D.C.C. \& da Silva W.R., 2012. Genetic analysis of total seed protein content in two cowpea crosses. Crop Sci., 52: 2501-2506.

[38] Sreerama Y.N., Sashikala V.B., Pratape V.M. \& Singh V., 2012. Nutrients and antinutrients in cowpea and horse gram flours in comparison to chickpea flour: evaluation of their flour functionality. Food Chem., 131: 462-468.

[39] Towo E., Svanberg U. \& Kamala A., 2003. Phenolic compounds, phytate, citric acid and the in-vitro iron accessibility of cowpeas, mungbeans and four varieties of kidney beans. Afr. J. Food Agric. Nutr. Dev., 3(1): 53-59.

[40] Vaintraub I.A. \& Lapteva N.A., 1988. Colorimetric determination of phytate in unpurified extracts of seeds and the products of their processing. Anal of Biochemistry,175: 227-230

[41] Vasconcelos I.M., Maia F.M.M., Farias D.F., Campello C.C., Carvalho A.F.O., Moreira R.A. \& Abreu de Oliveira J.T., 2010. Protein fractions, amino acid composition and antinutritional constituents of highyielding cowpea cultivars. J. Food Compos. Anal., 23: 5460.

[42] Volis S., Shulgina I., Zaretsky M.\& Koren O., 2010. Epistasis in natural populations of a predominantly selfing plant. Heredity, 106: 300-309.

[43] Warner J.N., 1952. A method for estimating heritability. Agron. J., 44: 427-430.

[44] Wright S., 1968. The genetics of qualitative variability. In: Wright S., (Ed.), Evolution and genetics of populations.
Vol. I. Genetic and biometric foundations. University of Chicago Press, Chicago, III. 